\title{
Carbothermal Upgrading of the Awaso Bauxite Ore using Sawdust and Coconut Shells as Reductant*
}

\author{
${ }^{1}$ A. Y., Fosu, ${ }^{1}$ N. Fosu, K. ${ }^{1}$ B. Owusu, and ${ }^{1}$ J. R. Dankwah \\ ${ }^{1}$ University of Mines and Technology, P.O. Box 237, Tarkwa, Ghana
}

Fosu, A. Y., Fosu, N., Owusu, K. B. and Dankwah, J. R. (2016), "Carbothermal Upgrading of the Awaso

Bauxite Ore using Sawdust and Coconut Shells as Reductant", Ghana Mining Journal, Vol. 16, No. 2, pp. 58 64.

\begin{abstract}
Ghana's bauxite is exported in the raw state with no value addition. One way to achieve value addition is to carbothermally upgrade the ore into magnetic and nonmagnetic fractions, followed by separation using a magnet. This work investigates the carbothermal upgrading of the Awaso bauxite ore using reductant generated from locally available saw dust (SD) and coconut shells (CNS). Composite pellets of bauxite-reductant were prepared, air-dried and cured for 72 hours. The cured pellets were placed in a fire-clay crucible and heated in a custom-made gas-fired furnace for 30 minutes. The fired composite pellets were separated into magnetic and non-magnetic portions using a low intensity hand-held magnet. The various portions were then characterised using XRD, XRF and SEM analyses. XRD results showed magnetite as the predominant species present in the magnetic fraction whilst the non-magnetic fraction showed alumina as the predominant peaks along with some traces of unreduced hematite, silica, carbon and titania but no hercynite.
\end{abstract}

Keywords: Bauxite, Palm Nut Shells, Gas-Fired Furnace, Hercynite, Char

\section{Introduction}

Coconut is cultivated in several parts of Ghana. The fruit is consumed locally, producing greater volumes of waste CNS which become a nuisance (Fig. 1a). Saw dust is a by-product, arising from wood processing whose disposal becomes a challenge due to the large volumes generated (Fig. 2a). This cheap and readily available biomass form part of the carbon cycle, produced through photosynthesis. They are "carbon neutral" renewable fuels which can be used as energy sources or raw materials to obtain high value products. They are biopolymer made of cellulose $\left[\mathrm{C}_{6}\left(\mathrm{H}_{2} \mathrm{O}\right)_{5}\right]_{\mathrm{n}}$, hemicellulose $\left[\mathrm{C}_{5}\left(\mathrm{H}_{2} \mathrm{O}\right)_{4}\right]_{\mathrm{n}}$ and lignin $\left[\mathrm{C}_{10} \mathrm{H}_{12} \mathrm{O}_{3}\right]$ (Dankwah, 2014; Zhou et al., 2006; Chattopadhyay et al., 2008; Vivero et al., 2005). When heated, the sugar units break down into cellulose and hemicellulose which escape as volatiles. Lignin is not easily cleaved and hence forms char during the process (Dankwah, 2014; Zhou et al., 2006; Chattopadhyay et al., 2008; Vivero et al., 2005). Charring increases the carbon content making it possible to generate a reductant from them to upgrade Ghanaian bauxite before exportation.

Bauxite, the principal ore of alumina (like most ores) has varying amount of gangue minerals which require removal during beneficiation process. The predominant gangue mineral is iron oxide, occurring as goethite and or hematite. Iron oxide impurity in Awaso bauxite ranges from $7 \mathrm{wt} \%$ to 50 wt \% depending on the depth and geographical local (Dankwah et al., 2015). Iron oxide impurity affects digestion and clarification steps in the Bayer process. Research by Basu and Nitowski, 1986, showed that, iron impurities have major impact on Bayer Process efficiency and quality of products; goethite, due to its distinctive surface properties coupled with its fine particle size (about 0.02-2.00 $\mu \mathrm{m})$ makes it difficult to settle in red mud. Dissolved and precipitated goethite may introduce undesirable colour in the final alumina and aluminium metal product. Ofori-Sarpong et al., 2014 in their research indicated that, bauxite used in refractory and ceramic industries must be as low as possible, generally, below $2 \%$ in order to avoid decolourisation of products.

The beneficiation of bauxite by the Bayer technology yields large volume of red mud. The volume of Bayer process red mud generation as reported by Hausberg et al., 2000 is between 1.1 and 6.2 tons per ton of alumina produced depending on the bauxite grade and technical processes. Research by Cablik (2007) and Samouhos et al., (2013) indicates that red mud generation can be reduced by at least $40 \mathrm{wt} \%$ if iron oxide mineral (goethite and hematite) is recovered as magnetite based on the composition of red mud. According to Parlikar et al., (2011), disposal of red mud in storage areas contribute to about $5 \%$ of the production cost. The large volumes generated in addition to its high caustic level, exceptionally slow drying rate and low physical strength poses serious environmental challenge (Hind et al., 1999). With the encounter of low grade bauxite, this volume is predicted to be higher. Removal of iron oxide from bauxite prior to its beneficiation is therefore a key to the reduction of the waste, hence curbing its environmental 
problem to some extent. The presence of iron oxide mineral may result in unusual reagent consumption and also interfere with the recovery of other impurities such as $\mathrm{TiO}_{2}$.

Various researchers have investigated into several ways of removing iron from bauxite (Dankwah et al., 2015; Sadler and Venkataraman, 1991; Papassiopi et al., 2010; Yeh and Zhang 2013; Lu et al., 2007; Lu et al., 2012). Lu et al., (2012) research revealed the formation of hercynite which prevented the separate recovery of iron and alumina.

This research seeks to generate a reductant from CNS and SD, use it to carbothermally upgrade the Awaso bauxite using the custom made gas-fired oven as energy source.

\section{Resources and Methods Used}

\subsection{Materials}

Metallurgical grade bauxite was obtained from Ghana Bauxite Company, Awaso in Ghana. CNS was obtained from coconut oil producers in Takoradi whilst SD was collected from a wood processing factory in Tarkwa. Riffling was used to sample and obtain a representative ore sample which was pulverised using a RETSCH pulveriser model 5657 and screened with a standard sieve of aperture size $180 \mu \mathrm{m}$ to obtain pulverised sample of $-180 \mu \mathrm{m}$ particle size (Fig. 3a). The pulverised sample was then characterised by XRD using an EMPYREAN Diffractometer with cobalt as the source of $\mathrm{X}$-rays and by XRF using X-ray Fluorescence SPECTROX-LAB-2000 whilst its morphology was observed using SEM. CNS and SD were charred for one hour and 30 minutes respectively, followed by pulverisation in RETSCH pulveriser model 5657. Size analysis of the pulverised reductants was conducted using a nest of sieves with $250 \mu \mathrm{m}$ as the topmost sieve (Fig. 1b and $2 \mathrm{~b}$ )

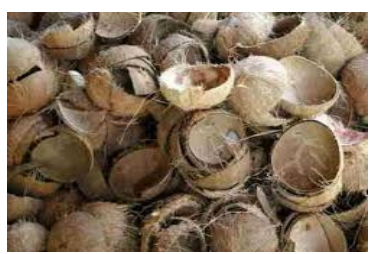

(a)

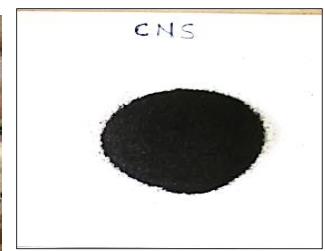

(b)
Fig. 1 (a) Waste Coconut Shells (b) Reductant Generated from Waste Coconut Shells

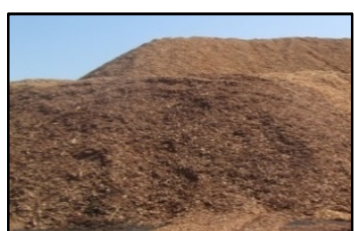

(a)

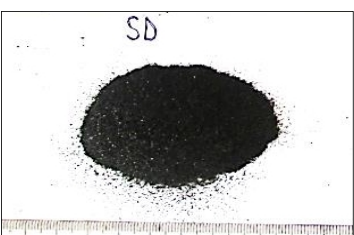

(b)
Fig. 2 (a) Heap of Waste SD (b) Reductant Generated from SD

\subsection{Formation of Pellets}

$50 \mathrm{~g}$ of the pulverised bauxite was mixed with about $1 \mathrm{~g}$ of the reductants at the various particle sizes. The mixtures were thoroughly mixed and made into paste by drop-wise addition of water. The paste was hand-rolled into spherical pellets, air dried and cured for five days. The final pellets were about $4 \mathrm{~cm}$ in diameter and weighed approximately 50.20 g (Fig. 3b).

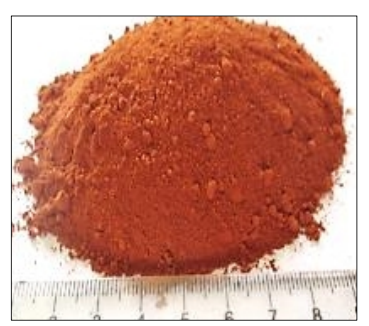

(a)

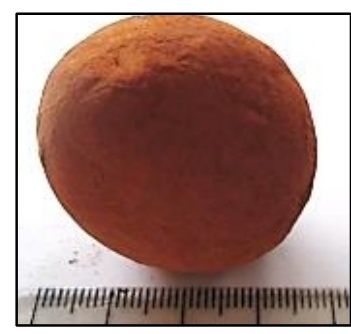

(b)
Fig 3 Bauxite Milled to $\mathbf{- 1 8 0} \mu \mathrm{m}$ (b) Composite Pellet of Bauxite-Reductant Mixture

\subsection{Experimental Set-up}

The reduction was carried out in the "sika bokyia furnace" - a custom-made gas-fired furnace. Basically, it consists of a cylindrical metal casing, lagged with ceramic fibre. The heat inlet is tangential to the periphery of the cylinder to allow uniform heat distribution. LPG was employed as the fuel (Fig. 4).

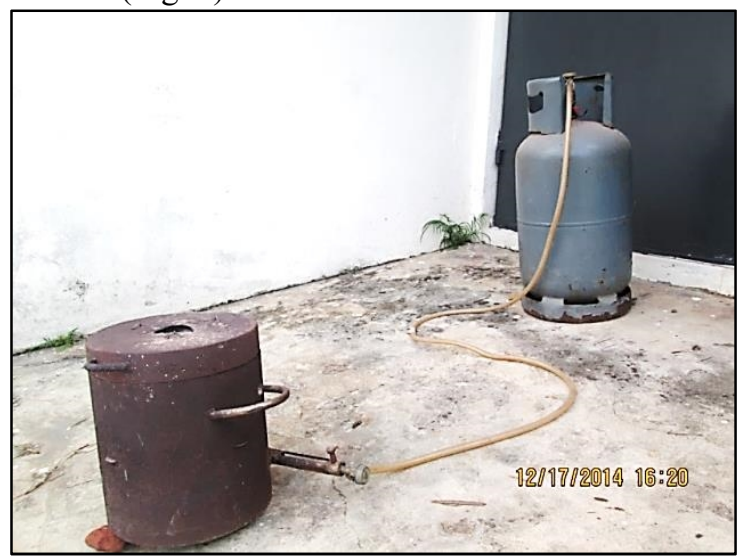

Fig. 4 Firing of Pellet in Progress

\subsection{Experimental Procedure}

Each of the pellets was placed in a fire clay crucible and heated for 30 minutes in the furnace. The heated samples were rapidly quenched under running water to avoid re-oxidation to $\mathrm{Fe}_{2} \mathrm{O}_{3}$. Dry magnetic separation was conducted on the sample using a low intensity handheld magnet to obtain the magnetic and non-magnetic fractions. Each portion 
was weighed and selected ones kept for XRD analysis.

\section{Results and Discussion}

Elemental and proximate analyses of the raw and charred PNS are shown in Tables 1 and 2, respectively.

Table 1 Typical Elemental Analysis of CNS and SD

\begin{tabular}{|l|l|l|l|l|l|}
\hline $\begin{array}{c}\text { Component } \\
\text { (wt \%) }\end{array}$ & C & H & S & N & O \\
\hline Raw CNS & 52.4 & 5.72 & 0.03 & 0.11 & 41.77 \\
\hline Raw SD* & 53.17 & 4.10 & 0.302 & 0.28 & 39.60 \\
\hline Char CNS & 78.1 & 3.49 & 0.01 & 0.15 & 17.55 \\
\hline Char SD** & 83.35 & 1.77 & 0.01 & 0.11 & 5.07 \\
\hline
\end{tabular}

(Source: *Akowuah et al., 2013; Dankwah, 2013, Dankwah, 2014; **Diebold and Scahill, 1985)

Table 2 Typical Proximate Analysis of CNS and SD

\begin{tabular}{|l|l|l|l|l|}
\hline Component & Moisture & Ash & $\begin{array}{l}\text { Volatile } \\
\text { Matter }\end{array}$ & $\begin{array}{l}\text { Fixed } \\
\text { Carbon }\end{array}$ \\
\hline Raw CNS & 8.5 & 0.87 & 87.5 & 11.6 \\
\hline Raw SD* & 5.7 & 2.6 & 71.0 & 20.7 \\
\hline Char CNS & 5.40 & 0.70 & 29.80 & 69.60 \\
\hline Char SD** & 2.02 & 5.67 & $<0.01$ & 92.31 \\
\hline
\end{tabular}

(Source: *Akowuah et al., 2013; Dankwah, 2013; Dankwah, 2014; **Diebold and Scahill 1985 )

It can be observed that, charring increased their carbon content. The presence of hydrogen and carbon in the elemental analysis infers the presence of some hydrocarbons.

\subsection{Possible reactions}

\section{Generation of reducing gases}

The generated reductants decompose during heating to produce $\mathrm{CO}_{2}, \mathrm{CO}, \mathrm{CH}_{4}$ and other hydrocarbons. Reduction by $\mathrm{CH}_{4}$ is not spontaneous at operating temperature $(500-900$ ${ }^{\circ} \mathrm{C}$ ). It does not cause any appreciable reduction. It rather decomposes on the surface of the oxide producing $\mathrm{H}_{2}$ and $\mathrm{C}$ (Equation 1) (Kawakami et al., 1998; Ghosh et al., 1986) or reacts with $\mathrm{CO}_{2}$ to produce $\mathrm{CO}$ (Equation 2). Carbon may be converted to $\mathrm{CO}$, according to the Boudouard reaction (Equation 3) or may directly cause reduction (Equation 10 to 12 ).

$$
\begin{gathered}
\mathrm{CH}_{4}=\mathrm{C}+2 \mathrm{H}_{2} \\
\Delta \mathrm{G}^{\circ}=91,040-110.7 \mathrm{~T}(\mathrm{~J} / \mathrm{mole}) \\
\mathrm{CH}_{4}+\mathrm{CO}_{2}=2 \mathrm{CO}+2 \mathrm{H}_{2}
\end{gathered}
$$

$\mathrm{C}$ may directly react and reduce the iron oxide or produce $\mathrm{CO}$ (Equation 3 ).

$$
\mathrm{CO}_{2}+\mathrm{C}=2 \mathrm{CO}
$$

$\mathrm{H}_{2}$ and $\mathrm{CO}$ are therefore, the predominant reducing gases in the process.
Reduction of iron oxide by the reducing gases

a) Sequential reduction of hematite by $\mathrm{CO}$

$$
\begin{aligned}
& \mathrm{Fe}_{2} \mathrm{O}_{3}+1 / 3 \mathrm{CO}=2 / 3 \mathrm{Fe}_{3} \mathrm{O}_{4}+1 / 3 \mathrm{CO}_{2} \\
& \mathrm{Fe}_{3} \mathrm{O}_{4}+\mathrm{CO}=3 \mathrm{FeO}+\mathrm{CO}_{2} \\
& \mathrm{FeO}+\mathrm{CO}=\mathrm{Fe}+\mathrm{CO}_{2}
\end{aligned}
$$

b) Sequential reduction of hematite by $\mathrm{H}_{2}$

$$
\begin{aligned}
& \mathrm{Fe}_{2} \mathrm{O}_{3}+1 / 3 \mathrm{H}_{2}=2 / 3 \mathrm{Fe}_{3} \mathrm{O}_{4}+1 / 3 \mathrm{H}_{2} \mathrm{O} \\
& \mathrm{Fe}_{3} \mathrm{O}_{4}+\mathrm{H}_{2}=3 \mathrm{FeO}+\mathrm{H}_{2} \mathrm{O} \\
& \mathrm{FeO}+\mathrm{H}_{2}=\mathrm{Fe}+\mathrm{H}_{2} \mathrm{O}
\end{aligned}
$$

c) Sequential reduction of hematite by $\mathrm{C}$

$$
\begin{aligned}
& \mathrm{Fe}_{2} \mathrm{O}_{3}+1 / 3 \mathrm{C}=2 / 3 \mathrm{Fe}_{3} \mathrm{O}_{4}+1 / 3 \mathrm{CO} \\
& \mathrm{Fe}_{3} \mathrm{O}_{4}+\mathrm{C}=3 \mathrm{FeO}+\mathrm{CO} \\
& \mathrm{FeO}+\mathrm{C}=\mathrm{Fe}+\mathrm{CO}
\end{aligned}
$$

Calcination of hydrated aluminium oxide to form alumina

$$
\mathrm{Al}_{2} \mathrm{O}_{3} \cdot \mathrm{XH}_{2} \mathrm{O}=\mathrm{Al}_{2} \mathrm{O}_{3}+\mathrm{XH}_{2} \mathrm{O}
$$

Formation of hercynite

$$
\mathrm{FeO}+\mathrm{Al}_{2} \mathrm{O}_{3}=\mathrm{FeAl}_{2} \mathrm{O}_{4}
$$

\subsection{Mineralogical Analysis of Raw Bauxite}

The XRF and XRD analyses of as received bauxite are presented in Table 3 and Fig. 5 respectively whilst Fig. 6 shows a photo of SEM. Observation indicates that the ore is low grade with $\mathrm{Fe}_{2} \mathrm{O}_{3}$ as the major impurity. Other gangue minerals significantly present are $\mathrm{SiO}_{2}$ and $\mathrm{TiO}_{2}$.

Table 3 Chemical Composition of Awaso Bauxite Ore Utilised for the Investigation

\begin{tabular}{|l|c|}
\hline Component & $\begin{array}{c}\text { Composition } \\
\text { (wt. \%) }\end{array}$ \\
\hline $\mathrm{SiO}_{2}$ & 1.45 \\
\hline $\mathrm{TiO}_{2}$ & 2.3 \\
\hline $\mathrm{Al}_{2} \mathrm{O}_{3}$ & 45 \\
\hline $\mathrm{Fe}_{2} \mathrm{O}_{3}$ & 25.88 \\
\hline $\mathrm{CaO}$ & 0.08 \\
\hline $\mathrm{MgO}$ & 0.11 \\
\hline $\mathrm{MnO}$ & 0.03 \\
\hline $\mathrm{V}_{2} \mathrm{O}_{5}$ & 0.02 \\
\hline $\mathrm{P}_{2} \mathrm{O}_{5}$ & 0.15 \\
\hline $\mathrm{Na}_{2} \mathrm{O}$ & 0.06 \\
\hline LOI & 24.95 \\
\hline TOTAL & $\mathbf{1 0 0 . 0 3}$ \\
\hline
\end{tabular}




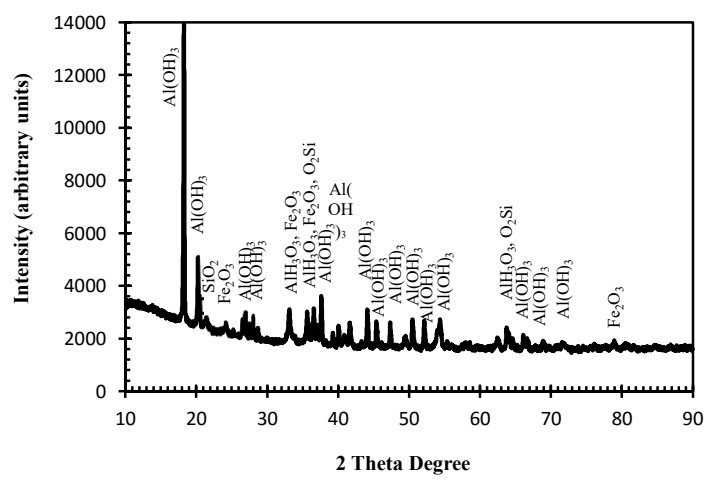

Fig. 5 XRD Diffraction Patterns of As-Received Awaso Bauxite
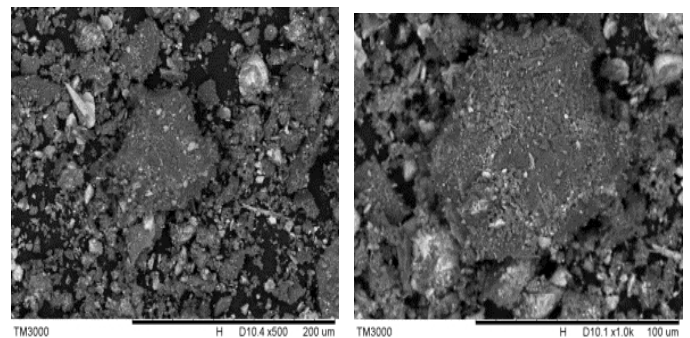

Fig. 6 SEM Photomicrograph of As-Received Awaso Bauxite Ore

\subsection{Chemical Analysis of Magnetic Fraction}

Fig. 7 shows the XRD pattern of the magnetic fraction obtained after reduction using CNS whilst Fig. 8 (a) and (b) shows the magnetic fraction extracted with a handheld magnet with its corresponding SEM respectively. Magnetite peaks are the predominant with few peaks of silica and carbon. Silica and carbon, though non-magnetic, appearing in the magnetic fraction infer sintering during the reduction process making them trapped up in the magnetic portion. The predominant magnetite peaks observed signifies active reduction of $\mathrm{Fe}_{2} \mathrm{O}_{3}$ by CNS.

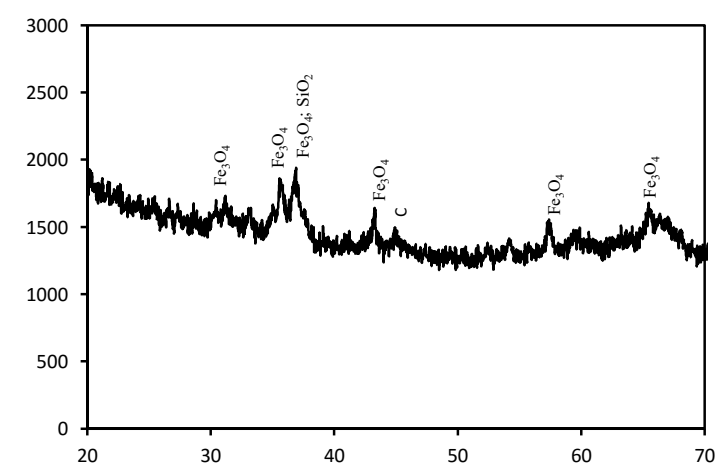

Fig. 7 XRD of Magnetic Fraction Separated after Reduction of Awaso Bauxite Ore with CNS

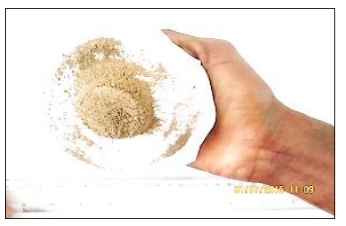

(a)

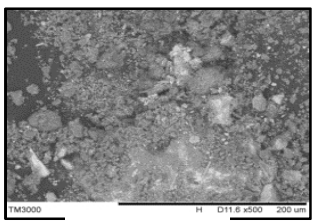

(b)
Fig. 8 (a) Magnetic Fraction Separated with a Handheld Magnet (b) SEM of Magnetic Fraction obtained after Reduction

The XRD patterns of the magnetic fraction obtained after reduction using SD is shown in Fig. 9. Its composition is observed to be similar to that of CNS; magnetite is the predominant peak with few peaks of silica and carbon.

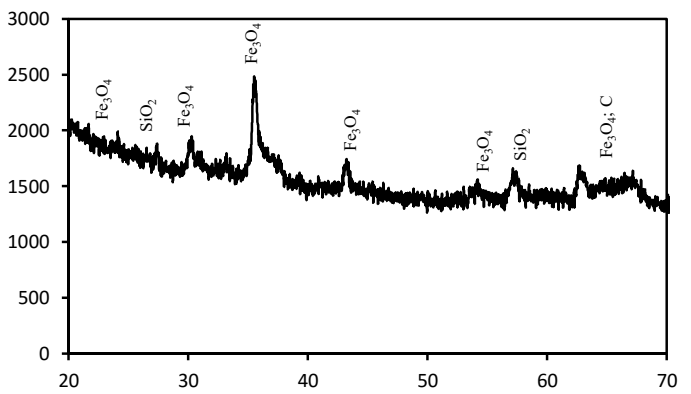

Fig. 9 XRD of Magnetic Fraction Separated after Reduction of Awaso Bauxite Ore with SD

\subsection{Chemical Analysis of Non-magnetic Fraction}

Fig. 10 shows the XRD patterns of the nonmagnetic fraction obtained after reduction using CNS whilst Fig. 11 (a) and 11 (b) indicates the non-magnetic portion extracted with its SEM respectively. Alumina, carbon and silica are the predominant peaks. Few peaks of titania and $\mathrm{Fe}_{2} \mathrm{O}_{3}$ were also observed. Peaks of alumina resulted due to calcination process in Equation 13. The presence of carbon in all the portions separated implies incomplete reduction reaction by carbon used. This is marked by presence of unreduced peaks of $\mathrm{Fe}_{2} \mathrm{O}_{3}$ in Fig. 7 and 9.

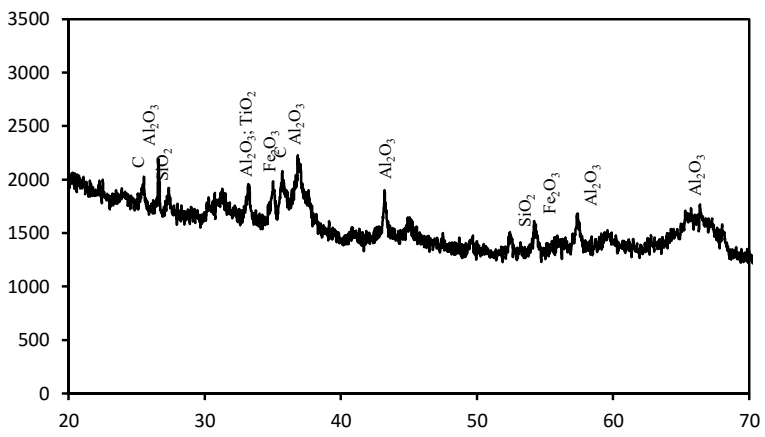

Fig. 10 XRD of Non-magnetic Fraction Separated after Reduction of Awaso Bauxite Ore with CNS 


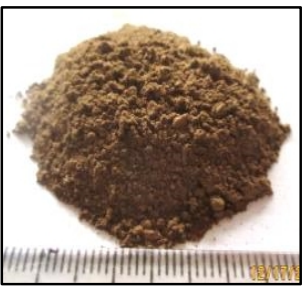

(a)

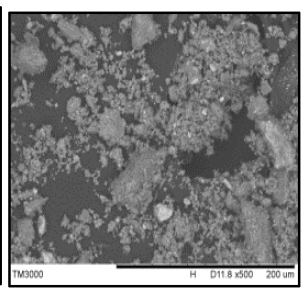

(b)
Fig. 11 (a) Non-magnetic Fraction obtained after Magnetic Separation (b) SEM of Nonmagnetic Fraction obtained after Reduction

The XRD patterns of the non-magnetic fraction obtained after reduction using SD is shown in Fig. 12. Its composition is similar that obtained for CNS. No peak of hercynite was observed in both cases, contrary to observations by Lu et al., 2012. However, charcoal like saw dust is a wood matter and a similar observation was expected.

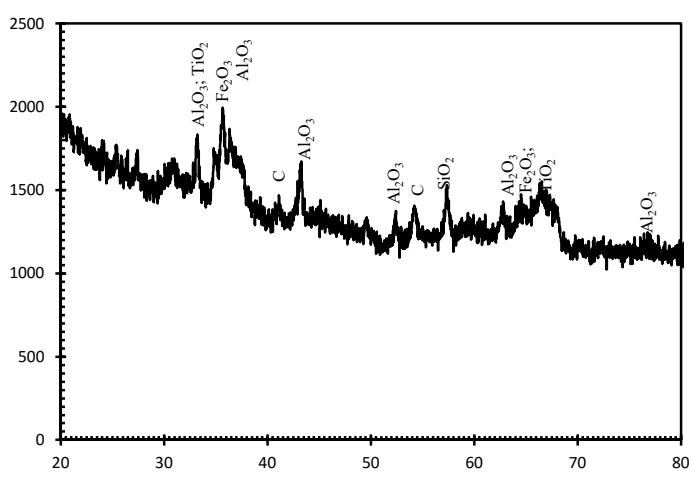

Fig 12 XRD of Non-magnetic Fraction Separated after Reduction of Awaso Bauxite Ore with SD

\subsection{Effect of Particle Size on the Masses of Magnetic and Non-magnetic Fractions}

Generally, there was no observed trend regarding the effect of particle size on the mass of magnetic and non-magnetic fractions obtained. This observation may be attributed to local sintering caused by fineness of polymer particle size. The sintering resulted in trapping some non-magnetic fractions in the magnetic fractions and vice-versa as observed in Fig. 7 and 9. It was however, observed that, at $+90 \mu \mathrm{m}$, appreciable reduction was obtained with the two reductants.

The effect of particle size on the masses of magnetic and non-magnetic fractions extracted using SD are shown in Fig. 13 and Fig. 14 respectively.

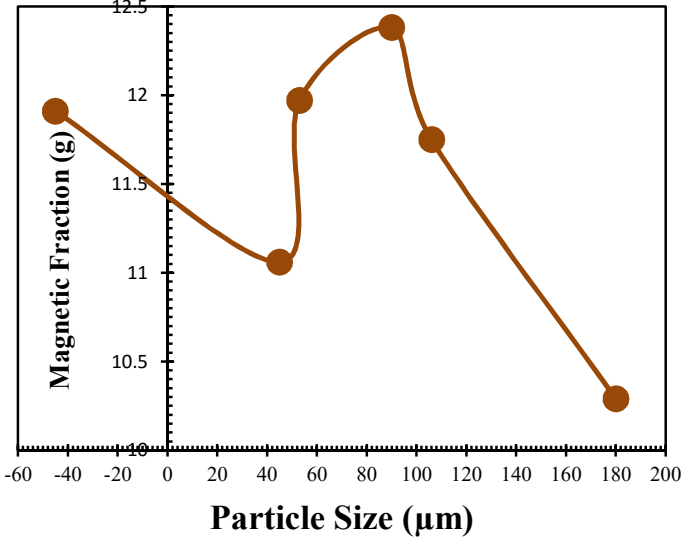

Fig. 13 Graph of Magnetic Fraction against Particle Size for SD

At $-45 \mu \mathrm{m}$, the quantity of magnetic fraction began to decrease from $11.91 \mathrm{~g}$ to $11.06 \mathrm{~g}$ at $+45 \mu \mathrm{m}$. It began to rise gradually until it reached its maximum at $+90 \mu \mathrm{m}$ with $12.38 \mathrm{~g}$ of magnetic fraction which began to decrease until it reached its minimum at the $+180 \mu \mathrm{m}$ with a minimum amount of $6 \mathrm{~g}$ magnetic fraction extraction.

The non-magnetic fraction was observed to have a minimum quantity of $22.78 \mathrm{~g}$ at $+90 \mu \mathrm{m}$ and the maximum quantity of $27.69 \mathrm{~g}$ at $180 \mu \mathrm{m}$.

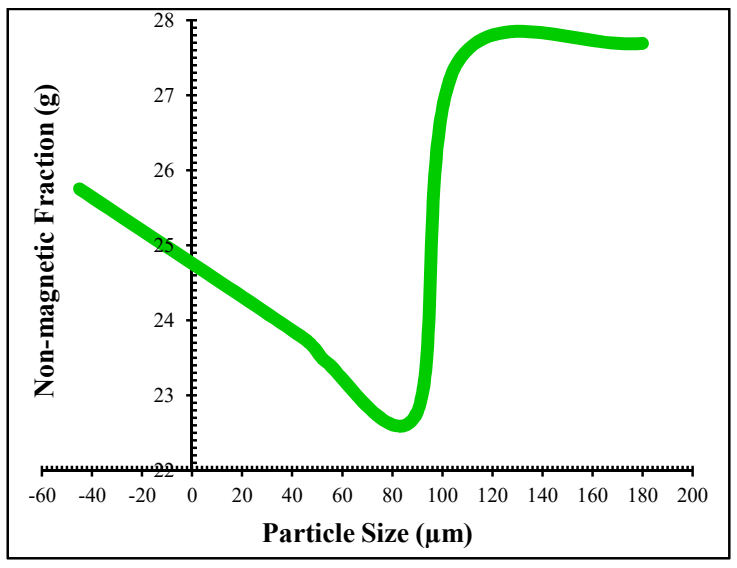

Fig. 14 Graph of Non-magnetic Fraction against Particle Size for SD

Fig. 15 and Fig. 16 show the effect of particle size on the magnetic and non-magnetic portions obtained respectively using CNS. A gradual increase of the magnetic fraction from $9.06 \mathrm{~g}$ at -45 $\mu \mathrm{m}$ until it reaches $11.31 \mathrm{~g}$ at $+53 \mu \mathrm{m}$ where it began to decrease to $10.28 \mathrm{~g}$ at $+90 \mu \mathrm{m}$. It then increased finally to $11.49 \mathrm{~g}$ at $+180 \mu \mathrm{m}$. The highest quantity of non-magnetic fraction is $26.10 \mathrm{~g}$ at $+106 \mu \mathrm{m}$ and the lowest was $24.89 \mathrm{~g}$ which occurred for $+53 \mu \mathrm{m}$. 


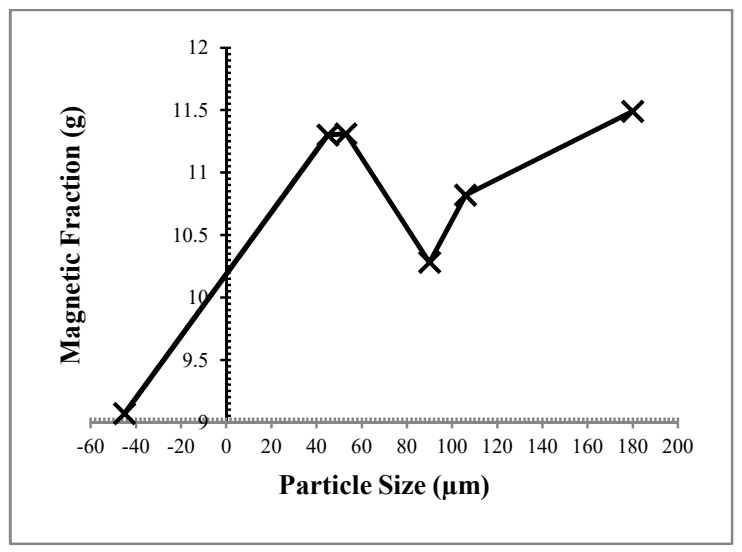

Fig. 15 Graph of Magnetic Fraction against Particle Size for CNS

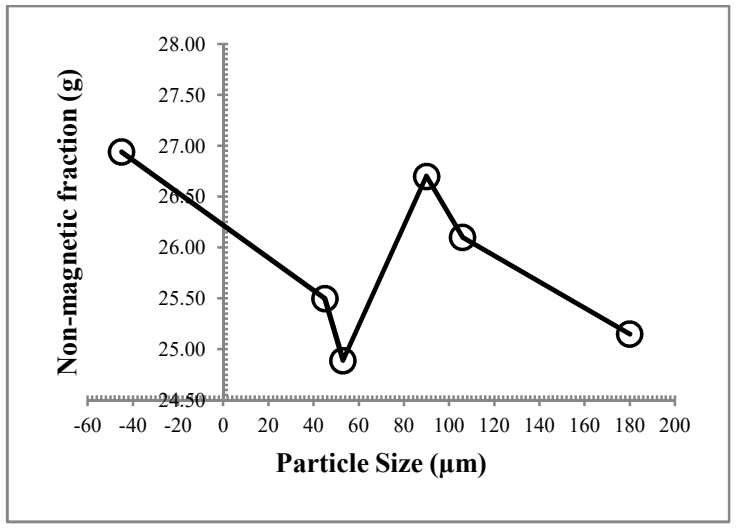

Fig. 16 Graph of Non-magnetic Fraction against Particle Size for CNS

An appreciable amount of magnetic fraction was obtained at or below $+90 \mu \mathrm{m}$. It is therefore advisable not to grind the polymers beyond +90 $\mu \mathrm{m}$.

The stability of $\mathrm{SiO}_{2}, \mathrm{TiO}_{2}$ and $\mathrm{Al}_{2} \mathrm{O}_{3}$ at the operating temperature resulted in their nonreduction to their respective metals or carbides, hence no peak of Si, Ti nor Al observed.

\section{Conclusions}

Saw dust and coconut shells can serve a dual purpose of environmental clean-up and upgrading Awaso bauxite. Fairly high amount of bauxite iron was converted to magnetite using small quantities of polymer (less than $2 \mathrm{wt} \%$ ) to achieve reduction; making this work exceptional from earlier works which made use of large quantities which will practically affect furnace efficiency.

Particle size used in this work did not show any defined trend for the quantity of magnetic and nonmagnetic fraction; however, lower polymer particle size of up to about $+90 \mu \mathrm{m}$ is found good enough to cause reduction and there is no need grinding to lower particle size which will increase cost but with no appreciable increase in reduction. Again, the absence of hercynite formation using the two biomass makes them promising to be used as reductant to upgrade Ghana's bauxite.

It is recommended that future works:

(i) Focus on polymer with higher particle size which might indicate the effect and trend on the quantity of magnetic and nonmagnetic portions extracted;

(ii) Extend the time used for heating beyond the 30 minutes used in this work.

\section{References}

Akowuah, J., O., Kemausuor, F. and Stephen M. J. (2012), "Physico-chemical Characteristics and Market Potential of Sawdust Charcoal Briquette", International Journal of Energy and Environmental Engineering, pp. 1-11.

Basu, P. and Nitowski, G., A. (1986) "Chemical interactions of iron minerals during Bayer digest and clarification", Proceedings of the International Symposium on Iron Control Hydrometallurgy, Vol. 223, pp. 223-244.

Cablik, V. (2007). "Characterization and Applications of Red Mud from Bauxite Processing",Gospodarka surowcami mineralnymi, vol. 23, No. 4, 32 pp.

Chattopadhyay, J., Kim, C., Kim, R. and Pak, D., (2008) "Thermogravimetric Characteristics and Kinetic of Biomass Co-pyrolysis with Plastics", Korean J. Chem. Eng., Vol. 25 No.5, pp. 1047-1053.

Dankwah, J. R., Fosu, A. Y., Fosu, N. and Koshy, P., (2015), "Carbothermal Upgrading of the Awaso Bauxite Ore using Waste Pure Water Sachets as Reductant", Ghana Mining Journal, Vol. 15, No. 1, pp. 64 - 72.

Dankwah, J., R. (2014), "Recycling Blends of HDPE and Coconut Shells as Reducing Agent for the Production of Metallic Iron from Iron Oxide $\left(\mathrm{Fe}_{2} \mathrm{O}_{3}\right)$ ", International Journal Of Scientific \& Technology Research, Vol. 3, Issue 1, pp. $40-46$.

Dankwah, J. R. (2013). "Recycling Blends of Waste Plastics and Biomass as Reducing Agent for the Production of Metallic Iron from Iron Oxide", International Journal of Engineering Science and Technology, Vol. 5, No.12, 1967 pp.

Hausberg, J., Happel, U., Meyer, F., M., Mistry, M., Röhrlich, M., Koch, H., and Krüger, J. (2000), “Global Red Mud Reduction Potential through Optimised Technologies and Ore Selection", Mineral Resources Engineering, Vol. 9, No. 4, pp. 407-420. 
Hind, A., R., Bhargava, S., K., and Grocott, S., C. (1999), "The Surface Chemistry of Bayer Process Solids: a review", Colloids and surfaces A: Physicochemical and engineering aspects, Vol. 146, No. 1, pp. 359-374.

Levin, E. M., Robbins, C. R., and Mcmurdie, H. F. (1964), Phase Diagrams for Ceramists, Reser, M. K (ed.), Ohio, The American Ceramic Society, 696 pp.

Lu, T., Pickles, C. A. and Kelebek, S. (2012), "Carbothermal Reductive Upgrading of a Bauxite Ore using Microwave Radiation", High Temp. Mater. Proc., Vol. 31, No. 2, pp. 139-148.

Lu, T., Pickles, C.A. and Kelebek, S. (2007), "Microwave heating behaviour of a gibbsite type bauxite ore", In Proceedings of Symposium on Light Metals in Transport Applications. MetSoc (CIM), Toronto, Ont. Canada, pp. 421-449.

Ofori-Sarpong, G., Abbey, C. E., Asamoah, R. K., and Amankwah, R. K. (2014). "Bauxite Enrichment by Microwave-magnetising Roasting using Saw Dust as Reducing Agent", American Journal of Chemical Engineering, Vol. 2. No. 5, 59 pp.

Papassiopi, N., Vaxevanidou, K., and Paspaliaris, I. (2010), "Effectiveness of Iron Reducing Bacteria for the removal of Iron from Bauxite Ores", Minerals Engineering, Vol. 23, No. 1, pp 25-31.

Parlikar, U., V., Saha, P., K. and Khadilkar, S., A. (2011), "Technological Options for Effective Utilization of Bauxite Residue (Red Mud) - A Review", International Seminar on Bauxite Residue (Red Mud), October 17-19, Goa, India, p. 3.

Sadler, L. Y., and Venkataraman, C. (1991). "A Process for Enhanced Removal of Iron from Bauxite Ores", International Journal of Mineral Processing, Vol. 31, No. 3, pp. 233246.

Samouhos, M., Taxiarchou, M., Tsakiridis, P. E. and Potiriadis, K. (2013), "Greek Red Mud Residue: A Study of Microwave Reductive Roasting followed by Magnetic Separation for a Metallic Iron Recovery Process", Journal of Hazardous Material, pp. 194-205.

Venkatadri, A. S. (1983), "Free Energy of Hercynite Formation". Transactions of the Iron and Steel Institute of Japan, Vol. 23, No. 6, pp. 539-542.

Vivero, L., Barriocanal, C., Alvarez, R. and Diez, M.A., (2005) "Effect of Plastic Wastes on Coal Pyrolysis Behaviour and the Structure of Semicokes", Journal of Analytical and Applied Pyrolysis, Vol. 74, issue 1-2, pp. 327-336.

Yeh, C. H. and Zhang, G. (2013). "Stepwise Carbothermal Reduction of Bauxite Ores", International Journal of Mineral Processing, Vol. 124, pp. 1-7.
Zhou, L., Wang, Y., Huang, Q. and Cai, J., (2006), "Thermogravimetric Characteristics and Kinetic of Plastic and Biomass Blends Copyrolysis", Fuel Processing Technology, Vol. 87, issue 11. pp. 963-969.

\section{Authors}

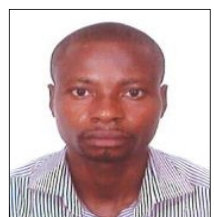

Allen Y. Fosu had his BSc degree in Chemistry from the Kwame Nkrumah University of Science and Technology, Kumasi. He is currently a postgraduate student at the Minerals Engineering Department, University of Mines and Technology, Tarkwa. $\mathrm{He}$ is currently working on carbothermal upgrading of the Awaso Bauxite ore using waste polymers and biomass as reductants.

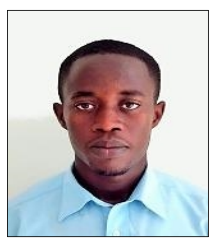

Nelson Fosu is a final year undergraduate student at the Minerals Engineering Department, University of Mines and Technology, Tarkwa, Ghana. $\mathrm{He}$ is currently working on the carbothermal upgrading of Awaso Bauxite using pure water sachets as reductant.

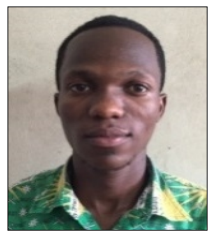

Kwaku Owusu Boateng is graduate from the Minerals Engineering Department of the University of Mines and Technology, Tarkwa, Ghana. He is currently a teaching assistant in the Department.

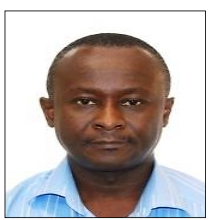

James R. Dankwah is a Senior Lecturer at the University of Mines and Technology (UMaT) Tarkwa. He holds $\mathrm{PhD}$ from the School of Materials Science and Engineering, UNSW-Australia, MSc (Process Metallurgy) from the Norwegian University of Science and Technology and BSc (Metallurgical Engineering) from the Kwame Nkrumah University of Science and Technology, Kumasi, Ghana. His current research areas include iron and steelmaking, hightemperature metallurgical processes, utilisation of waste polymers in metal extraction processes and recycling agricultural waste into building blocks materials for affordable housing for rural folks. 